\title{
A policy note on telecommunications reform in Algeria
}

\author{
Paul Noumba UM', \\ Lead Infrastructure Specialist, World Bank Institute \\ The World Bank Group \\ 1818 H Street, NW, Washington, DC USA 20433 \\ Tel. 1.202.473.0151 - Fax. 1.202.676.9874 \\ Email: pnoumbaum@worldbank.org
}

\begin{abstract}
By the end of the 1990s, most developed and many developing countries had liberalized their telecommunications markets to improve service accessibility and affordability to both businesses and households. In contrast, Algeria still managed its telecommunications sector as public property. The Ministry of Post and Telecommunications set the policy, enforced regulation and was in charge of service provision. The sector suffered from huge supply shortages, the waiting list lengthened, the quality of service deteriorated and overall the fiscal situation was unbalanced. In 1999, a new government appointed in the aftermath of President Bouteflika's election decided to change the situation and launched a comprehensive sector reform. This note reviews progress made in implementing this reform, discusses its preliminary impact, and comments on the main lessons learned. The note shows that by restraining arbitrary administrative action during the reform implementation, the government of Algeria laid the foundation for sustainable growth in the telecommunications sector.
\end{abstract}

JEL Classification:

L96 - Telecommunications, L98 - Government policy

World Bank Policy Research Working Paper 3339, June 2004

The Policy Research Working Paper Series disseminates the findings of work in progress to encourage the exchange of ideas about development issues. An objective of the series is to get the findings out quickly, even if the presentations are less than fully polished. The papers carry the names of the authors and should be cited accordingly. The findings, interpretations, and conclusions expressed in this paper are entirely those of the authors. They do not necessarily represent the view of the World Bank, its Executive Directors, or the countries they represent. Policy Research Working Papers are available online at http://econ.worldbank.org.

\footnotetext{
1 - The author is grateful to very useful comments provided by Antonio Estache, Yann Burtin, Pierre Guislain and Zoubida Aloua, on a preliminary version of this paper.
} 


\section{INTRODUCTION}

By the end of the 1990s, most developed and many developing countries had liberalized their telecommunications markets to improve service accessibility and affordability to both businesses and households. Although international experience demonstrated that enhanced competition through increased private participation in the provision of telecommunications services, and the implementation of sound regulatory policies for residual monopolistic segments were key ingredients for sector growth and development, Algeria still managed its telecommunications sector as a public property in accordance with article 17 of its constitution ${ }^{2}$. The resulting inadequate institutional framework led to numerous inefficiencies as expressed by a growing waiting list, distorted tariffs, poor service quality, and limited variety of services offered to consumers. Algeria lagged behind neighboring countries despite a substantial amount of public investment in the sector during the 1970s and part of the 1980s. In 1999, a new government appointed in the aftermath of President Bouteflika's election decided to change that situation and launched a comprehensive sector reform. The objectives of the government were: (a) to adapt and modernize the sector institutional framework to meet the national communication needs for the twenty first-century, (b) to allow increased private sector participation through the implementation of sound market liberalization policies, and (c) to preserve employment losses during the reform implementation. The implementation of sound market liberalization policies was considered to be the driving factor of the sector restructuring effort.

This note reviews progress made in the implementation of the sector reform, discusses preliminary results achieved, and highlights the main lessons learned during this process. The note shows that by restraining arbitrary administrative action during the reform implementation, the government of Algeria laid the foundation for sustainable growth and development in the telecommunications sector. The remainder of the note is organized in four sections. Section 1 reviews the sector background and analyzes the main compelling factors that shaped the reform agenda. Section 2 discusses the main components of the reform program, while section 3 attempts a preliminary impact assessment of the reform nearly three years after its beginning. Although, it is too early to derive a conclusive assessment, most observers admit that most development objectives have been achieved. Section 4 reviews the main lessons learned in terms of regulatory policy development, namely in the area of developing independent regulatory processes in an

\footnotetext{
2 - This provision was restated in the 1996 constitution.
} 
institutional framework that concentrates most of the executive branch power in the presidency of the republic. Concluding remarks are provided at the end of the paper.

\section{SECTOR BACKGROUND PRIOR TO THE REFORM}

Since the country's independence in 1962, post and telecommunications activities were listed under the constitution as public properties belonging to the national collectivity, and therefore entitled to public monopoly. Further, Ordinance 75-89 of December 1975 governing the activities, organization and operations of the ministry of post and telecommunications also stated the scope of the public monopoly to be exerted by the ministry. As a matter of fact, a supplementary budget, known as the "budget annexe des PTT $^{3 \prime}$, was established by the parliament in the early 1970 s to allow the ministry to fulfill its numerous missions. The "budget annexe" provided a certain level of management and financial flexibility. For instance, the ministry was allowed to directly mobilize hard currency loans to finance its investment program under an umbrella investment program negotiated and agreed with the Ministry of Finance. Moreover, the ministry was allowed to service its financial debt, and did not depend on the government general budget for that. The establishment of a "budget annexe" was after all a "de facto" recognition that the post and telecommunications activities were to be treated differently to any other public administration activities. Despite this early initiative to adapt the sector institutional environment, no major reform will be implemented until 1999. Indeed, Algeria was one of the few countries worldwide where post and telecommunications services were provided by a government department (ministry).

Despite the modernization effort engaged in the 1970s and part of the 1980s, the telecommunications network was mainly characterized by : (a) shortages of supply, (b) obsolete technology, (c) poor quality of service, (d) unbalanced tariff structure, namely very high tariff for long distance communications and abnormally low rates for local communication and monthly subscription charges, (e) limited variety of services. From 1975 to 1981 the Algerian government had made significant investments to upgrade and expand its public telecommunications network. Up to 1980, public investments in the telecommunications sector consistently represented between 0.3 and $0.6 \%$ of the country's GDP (see Fig.1). From 1980 onward, public investment decreased from 0.40 to $0.20 \%$ of GDP, which was not enough to satisfy

\footnotetext{
3 - Because the Ministry of post and telecommunications generated revenues from the commercialization of its services to consumers and businesses, a budget annex was established to provide additional financial flexibility as required by its operations. The Ministry was granted with a supplemental budget financed by revenues derived by its own operations.
} 
increasing new demand. During this period, public investment in telecommunications only represented an average of 0.70 to $1 \%$ of the gross fixed capital in Algeria against a standard industry ratio of $3 \%$ (see Fig.2).

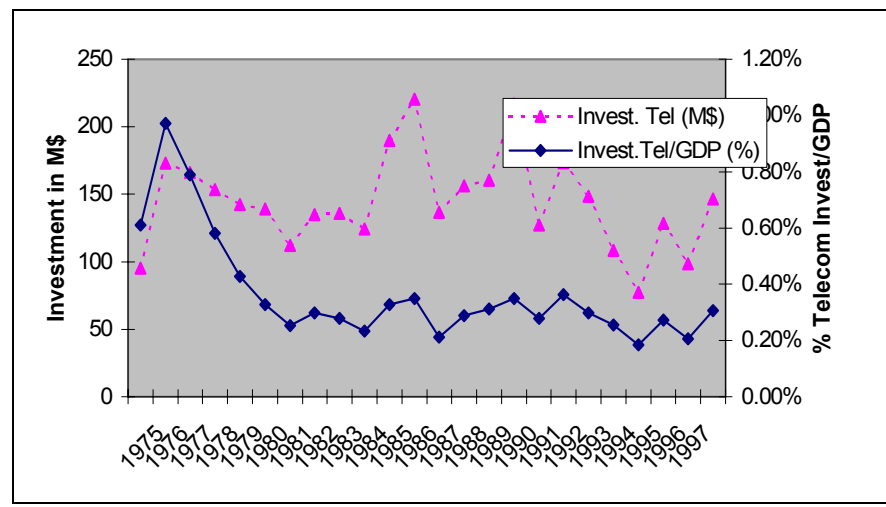

Fig. 1: Public investment in telecom.

Source: ITU, World Telecommunication Indicators, 2002

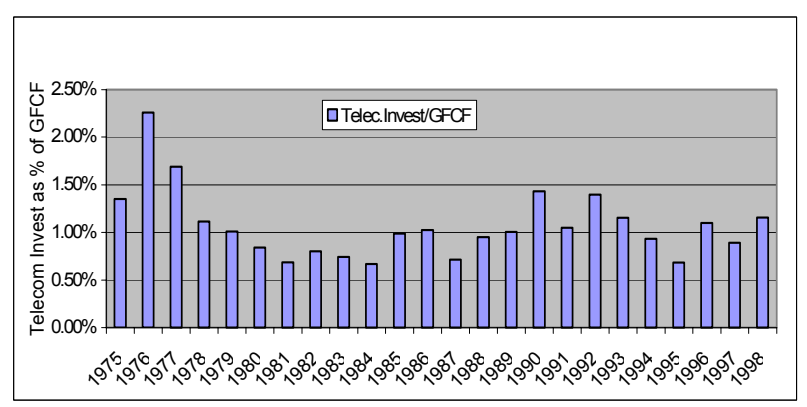

Fig. 2: Telecom investment as \% of Gross Fixed Capital Formation

As a result of public investment reduction, the waiting time for telephone connections lengthened and reached seven years at the beginning of the 1990s. The unmet demand was estimated in 2000 at 800,000 for fixed lines, and 600,000 for mobile phones (see Fig. 3). The quality of service deteriorated while faults became more frequent. Service quality and staff productivity were low. In 1998 only $66 \%$ of faulty lines were back in service within 48 hours, while in 2000 there were 98 main lines per employee.

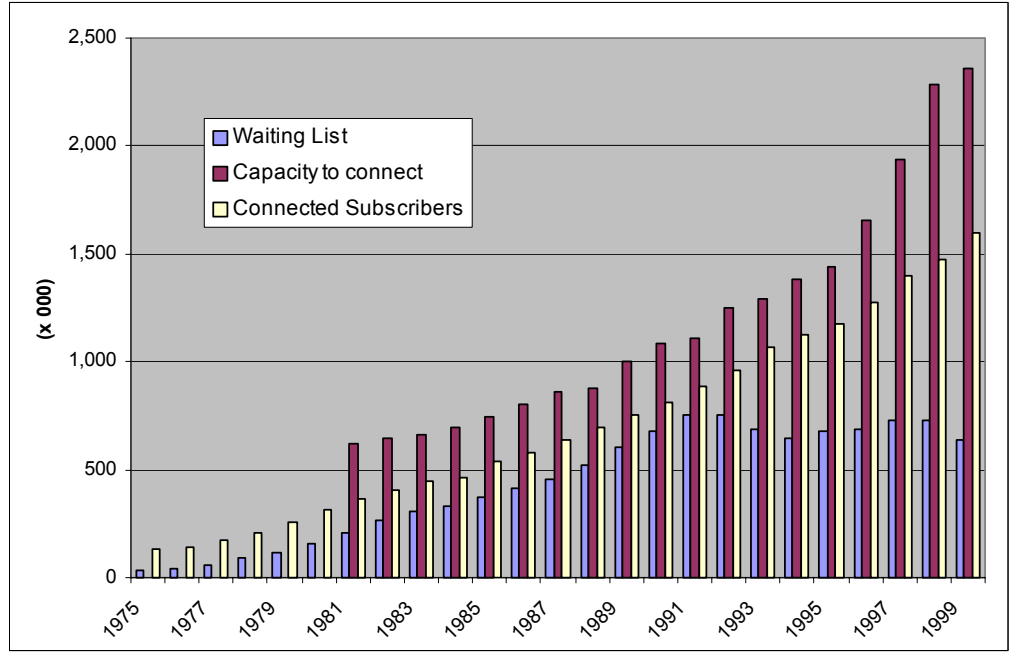

Source: ITU data.

Fig. 3: Telecommunications supply inefficiencies 
In comparison with other countries of the region, telephone tariffs in Algeria were generally kept low in regard to connection, subscription charges and local calls. However, tariffs for international calls were very high, between US $\$ 0.72$ per minute for calls to Southern Europe and US\$2.13 to Asia in 1998. Only international calls to neighboring countries were relatively competitive and were on average priced at US\$0.20 per minute. Most importantly, telephone tariffs were not cost based, but administratively decided in light of political and social considerations. In other words, the few that were connected to the telephone network benefited from most of the cross-subsidies, thus significantly impairing the ministry's capacity to increase investment. As a result, the telephone density was low at around 57 telephones per 1,000 people. This ratio remained largely static over the past 10 years. Tunisia and Egypt, with a similar telephone density in the early 1990s, outstripped Algeria by the end of the decade (see Fig.4). This is also shown by a simple econometric analysis performed on a sample of seven Mediterranean countries (Algeria, Greece, Spain, Egypt, Morocco, Portugal, and Turkey). The cross-section is for year 1998, and the regression model explains the evolution of the number of main telephone lines per inhabitant (teledensity [d]) by the following three variables : GDP per capita [GDP/Capita], weight of telecommunication investment in the gross fixed capital formation [InvTel/GFCF], and telecommunications operators' workers productivity [ML/Empl].

$$
\begin{gathered}
\log (d)=\underset{(-4.05)}{2.56}+\underset{(0.34)}{0.13} \log \left(\frac{G D P}{\text { Capita }}\right)+\underset{(1.07)}{0.13} \log \left(\frac{\operatorname{InvTel}}{G F C F}\right)+\underset{(3.23)}{1.39} \log \left(\frac{M L}{E m p l}\right) ; R^{2}=0.98 \\
\mathrm{n} \text { (number of observations) }=28
\end{gathered}
$$

Equation 1 [eqn. 1] shows that GDP/Capita or InvTel/GFCF variables are not relevant explanatory variables for the sample of countries studied. ${ }^{4}$ On the contrary, gradual improvement in the operators' productivity seems to have been the main explanatory factor. According to the model, teledensity in Algeria would have reached $7.14 \%$ in 1998 instead of the $5 \%$ observed.

\footnotetext{
${ }^{4}$ The coefficients (estimators) are not significant for these two variables.
} 
Fig. 4: Teledensity of fixed lines in a sample of North African countries

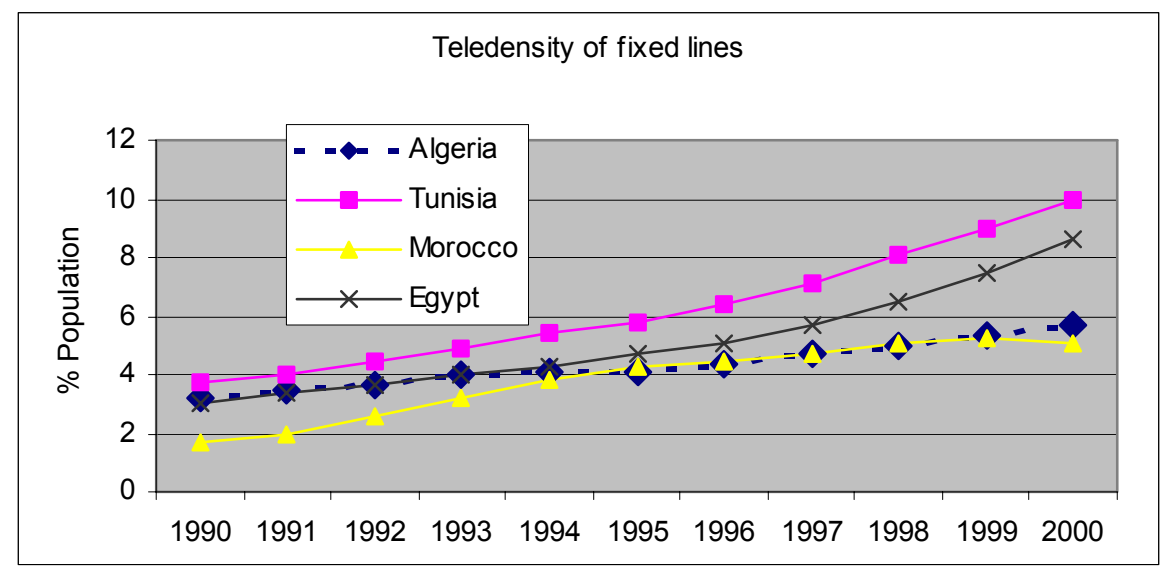

Source: ITU data.

The slowing down of the public investment effort does not therefore totally explain the underperformance of the sector. In fact, the performance of the ministry of post and telecommunications during these years did not deviate from the overall performance observed in the rest of the economy (World Bank, 2002). Algeria was locked in a command economy involving large inefficient and overstaffed public administrations or enterprises. The poor performance of the telecommunications sector was probably due to inappropriate structural organization. The authorities wanted to change that situation and launched a comprehensive sector reform in 2000.

\section{THE REFORM PROGRAM -}

In December 1999, the telecommunications network in Algeria counted approximately 1,600,000 fixed lines and 72,000 mobile subscribers. The number of Internet subscribers was estimated at 20,000 and cybercafes were only available in large towns. With respect to the country income per capita, connectivity was low and overall in poor condition. Conversely, the post and telecommunication ministry employed around 45,000 civil servants, and its labor unions were among the most powerful in the country. When the government announced its intent to reform the sector, most domestic and international observers expressed their skepticism. There was indeed a strong political will to proceed with a fast track but comprehensive telecommunications reform. The main objectives of the government were: (a) to use a successful telecommunications reform as a catalysis to structural reforms in other industries or sectors, and (b) to raise substantial fiscal proceeds through the sale of licenses. To achieve both objectives, the government pledged to implement market liberalization measures through competitive and transparent 
tenders, and decided to establish a sound regulatory framework conducive to private sector participation. This section will discuss the three main components of the reform program (World Bank 2000): (a) policy and regulatory framework, (b) financial, organizational restructuring, and privatization, and finally, (c) implementation of market liberalization policies.

\subsection{Policy AND Regulatory FRAMEWORK}

The Algerian government opted for a thorough reform of its post and telecommunications sector in order to face the challenges of the $21^{\text {st }}$ century, and to guide the country toward becoming an information society. This reform was dictated by the necessity to ensure the competitiveness and the diversification of the Algerian economy, and to promote the development of a competitive and dynamic telecommunications sector. The reform was to be implemented in the context of increased globalization and pending Algerian membership in the WTO. The implementation of the Association Agreement with the European Union was also an additional incentive to reform. The Government wanted to catch up with global telecommunications sector developments, and according outlined its reform agenda through the following main objectives:

- Increase the supply of and facilitate access to telecommunications services for the largest number of users. The government was committed to satisfy the demand for telephone services (business and residential) and make these services affordable to all, including the poorest.

- Improve quality, and widen the range of services offered. The government wanted to undertake necessary steps in order to improve the telecommunications sector's performance within five years and provide the Algerian households and businesses with modern but affordable information and communication services.

- Ensure access to telecommunications services and information networks by the rural population and other disadvantaged groups. The government foresaw the impact that rural connectivity will have on achieving a balanced economic development, as well as its powerful contribution in curbing out insecurity. The government was convinced that improving connectivity in remote areas would also improve their overall inclusion in the Algerian society.

- Develop a reliable national telecommunications network connected to the Internet. The government considered that the telecommunications reform was key to modernizing the public administration, and private companies, and the prerequisite for the expansion of electronic commerce. 
In sum, the government was convinced that a sound telecommunications reform will make its economy more competitive and less vulnerable to the volatility of oil revenues ${ }^{5}$. The reform would facilitate the emergence of new economic activities and the creation of new direct and indirect employment, and thus facilitate structural reforms in other industries or sectors.

In May 2000, the government issued a policy statement outlining the telecommunications liberalization program expected to be implemented in five years (2000-2005). The first step involved the preparation and enactment of a new set of legislations conducive to private sector participation and abolishing the public monopoly over the provision of telecommunications networks and services. The law was enacted in August 2000. A new regulatory body (ARPT) was created to take over regulatory functions previously handled by the ministry of post and telecommunications. The latter was subsequently reorganized to cope with its new mandate. The primary legislation was improved to ensure sound independence to ARPT. Nevertheless, ARPT's independence was after all limited. For instance, all the members of its board of directors were to be appointed by the president of the Republic, and liable to his discretionary dismissal. As in most civil law countries with strong presidential regimes, the pre-eminence of the executive branch over the parliamentary and the judiciary did in fact allow little flexibility on this area. However, the independence of ARPT was sound on two areas : financial autonomy and decision making process. In fact, the line minister had very limited authority over regulatory decisions or processes. The latter could be appealed to the Administrative court, but not to the ministry of telecommunications. Conversely, the preparation of new legislations (primary or secondary) and most policy decisions related on licensing or market structure were to be reviewed by ARPT, though the government could opt not to comply with any of these recommendations ${ }^{6}$. According to the sector law, the minister was empowered to formulate the sector policy and to oversee its implementation. For instance, the minister will issue individual licenses, whereas ARPT will instruct the licensing process. In case of disputes between ARPT and the minister, an arbitration process was to be handled by the General Secretariat of the government. Regarding disputes between operators or service providers, only the parties involved could be heard by the regulator (ARPT). In general, consumers were provided minimal access to regulatory process. Overall, the regulatory process, by inception, provided little room for an explicit due process and did not ensure public hearings prior to the enactment of regulatory decisions. Of course, public consultations could be organized by the regulator,

\footnotetext{
${ }^{5}$ - Hydrocarbon revenues account for $95 \%$ of Algeria total export revenues, or $75 \%$ of the government fiscal revenues.

${ }^{6}$ - see the discussion on the VSAT licensing in section xxxx.
} 
although this was not embodied in the legislations. One should however admit that establishing an open regulatory process was beyond any realistic expectation in Algeria by the time the reform was engaged. Regulatory practice was to be developed from scratch and the general public was not yet prepared to play an effective advocacy role despite a certain development of political pluralism and freedom of expression.

\subsection{MARKET STRUCTURE, FINANCIAL RESTRUCTURING AND PRIVATIZATION}

The sector policy and law 2000-03 set the market structure. The goal was to move progressively from a monopolistic market structure to a fully liberalized one. However, it worth recalling the public monopoly was breached by the enactment of a decree 1998 liberalizing the provision of Internet services (World Bank, 2003). Despite that breach only few private operators entered the Internet market. The lack of competitive access to international backbone was underscored as the main bottleneck. In implementing the telecommunications reform, the government decided to separate operational activities from policy formulation and regulation, and committed to strengthen public telecommunications infrastructures (see Fig. 6). For instance (World Bank 2003, page 41-43), two important infrastructure projects were launched in parallel to the reform the implementation. The first project related to the construction of the Algiers-Palma submarine cable connecting Algeria to Spain and offering a total bandwidth of $160 \mathrm{Gbps}$. The second project related to the roll-out of an Internet platform offering national and international backbone connectivity to Algerian ISPs. Both projects were completed respectively in 2001 and 2002. In launching these projects, the government's objective was to expand and upgrade the main transmission facilities and accommodate new entrants' bandwidth needs.

Two entities were created to take over the operational activities from the ministry. Algérie Telecom (AT) was established as a public corporation to be listed later on the Algiers stock market, whereas Algérie Poste (AP) was created as a state enterprise. Both entities were kept vertically integrated. Law 2000-03 required vertical separation between competitive and non competitive activities. Consequently, AT was required to establish an affiliate company for its mobile activity for which an individual license was subsequently issued. It is important to note that the GSM license granted to AT mirrored obligations and rights embedded in the license granted to the second private operator (Orascom Telecom Algérie). In contrast, other competitive services provided by AT prior to the enactment of law 2000-03 were bundled into a general license. For instance, international, long distance and local loop telephony activities were subject to individual licensing according to law 2000-03, whereas AT's general license involved all these 
services. AT was granted exclusivity on the local loop until December 2004, but was to be progressively exposed to competition on all its activities.

The reform was designed to address regulatory policy and organizational restructuring issues simultaneously. AT was established as a public corporation with the perspective to be privatized by the end of 2004. But its transformation from a government department into an autonomous commercial entity proved to be a very complex task. Indeed, it is in this area that the reform suffered most from the country's legacy in terms of political and social resistance to structural transformation. Created by law in August 2000, AT's statutes were adopted by the government in April 2001, while its operating licenses were issued in May 2002, and subsequently supplemented in January 2003. The corporate restructuring was indeed a politically sensitive process. For instance, the appointment of the CEO was stalled for 12 months. Furthermore, the preparation of opening balance sheets and other financial statements could not be completed in 12 months as initially planned. The financial auditors were unable to certify the accounts because of substantial inconsistencies, and incompleteness of available public accounts. The other major difficulty related to the scarcity of managerial skills of the staff inherited from the ministry of post and telecommunications. Further, skills in core business operations (marketing, strategy and planning, human resource development) were lacking. Without enough qualified staff to quickly turn around a centennial public administration into a commercial company, the privatization of AT initially scheduled in 2003 was postponed to post 2005. It was assumed that the implementation of a fast track privatization strategy was crucial in quickly turning around AT into a commercial entity. The transition from public to private management was expected to be short, and was planned to take approximately three years. This assumption proved to be wrong.

However one could ask why the corporate restructuring dimension of the reform, including the incorporation of AT, did not trigger the implementation of the liberalization plan. The point is relevant, but its implications would have delayed the implementation of market liberalization policies until AT's incorporation was completed. Indeed, it is obvious that the transformation of AT from a government department into a commercial firm needed more time. It is therefore unlikely that putting the stress on corporate restructuring would have led to a reform breakthrough. The government opted in favor of market liberalization instead of narrowing the reform agenda to the preparation or the transformation of one of the market players. Conversely, effective implementation of market liberalization policies was likely to provide quick 
demonstrative effects in terms of service availability and affordability. The decision to proceed with the sale of a second GSM license was therefore made, and thus guided the rest of the reform agenda.

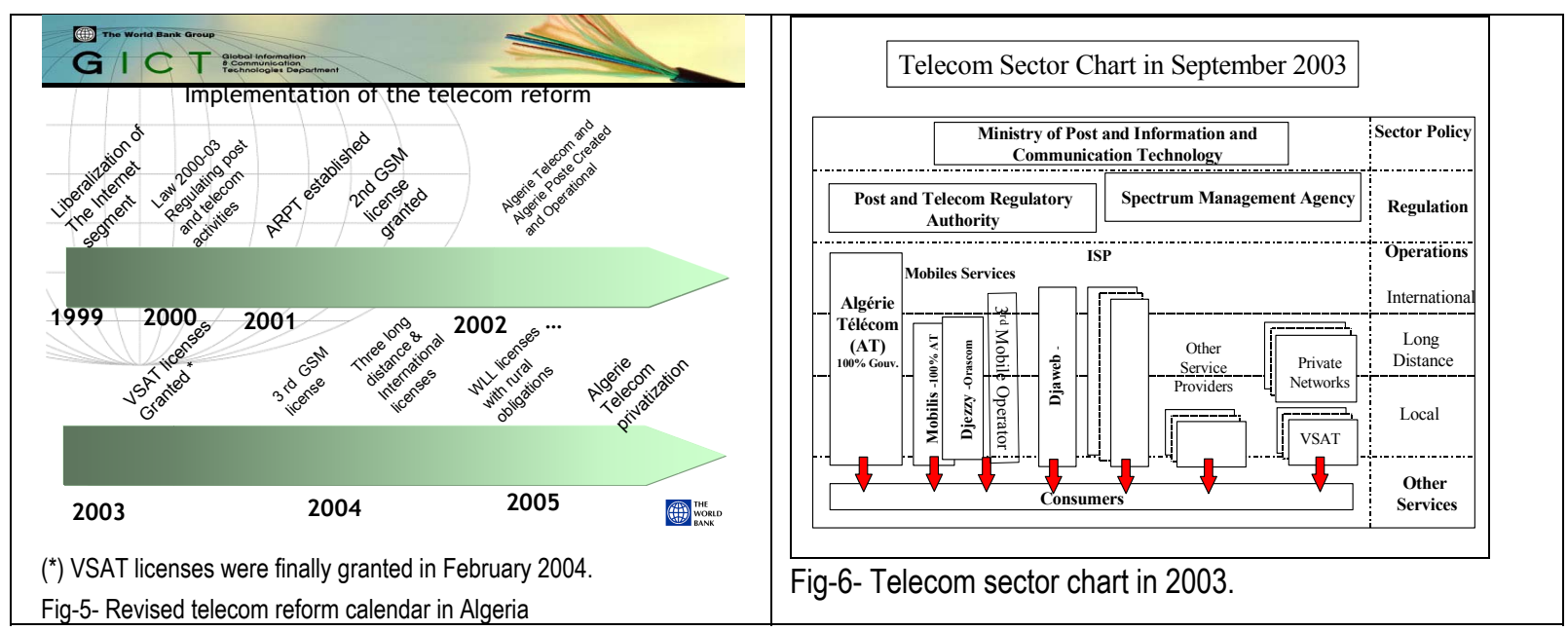

\subsection{IMPLEMENTATION OF SOUND MARKET LIBERALIZATION POLICIES}

The government decided to introduce competition in all market segments. The liberalization program adopted in 2000 was indeed ambitious, and proved to be beyond the government's implementation capacity. The government intended to grant 5 to 10 new licenses from 2001 to 2005. These licenses included: (a) a second GSM in 2001, (b) two VSAT licenses in $2001^{7}$, (c) at least two rural telephony operators licenses in 2002, (d) at least two international and long distance telephony operators licenses in 2003, (e) a third GSM license in $2003^{8}$, (f) local loop operators' licenses in 2004. Although its implementation was delayed (see Fig-5.), the government's goal in designing such an ambitious liberalization program was to convey a strong signal on its commitment to open up the Algerian economy. The telecommunications liberalization was to illustrate that commitment in practice. More realistic alternatives were considered, but were abandoned because the government was convinced that a less ambitious program would unlikely deliver the radical changes needed.

\footnotetext{
7 - In early 2002, the government of Algeria launched a public tender in view to license two VSAT (Very Small Aperture Terminal) operators. The process managed by the regulator (ARPT) led to the selection of two operators offering US $\$ 500,000$ for each license. Decrees granting the licenses to the selected operators were submitted to the cabinet for approval by the line minister in June 2003, but were turned down and the process cancelled. In September 2003, the government launched a second attempt to award these VSAT licenses. The new process concluded in February 2004 with the two licenses granted to Divona Telecom (an affiliate of Monaco Telecom) and OTA for around US $\$ 2$ million each.

${ }^{8}$ - Which was granted in December 2003.
} 
The second GSM licensing process was organized in two stages. At stage 1, the government pre-qualified potential bidders satisfying specified technical criteria as of March 31, $2001^{\circ}$. However, and according to the tender rules released in May 2001, the government could pre-qualify a company not meeting the last two criteria. It is on this basis that Orascom Telecom Holding $\left(\mathrm{OTH}^{10}\right)$ was pre-qualified. Pre-qualified bidders were invited to submit financial bids at stage two. The bidder offering the highest financial price will be granted the license. A two-stage process, involving technical qualification and a sealed envelope auction stage, was retained because it ensured maximum transparency as opposed to a standard beauty contest approach.

The second GSM licensing proceeded on a timely pace and the license was awarded in July 2001 to Orascom Telecom Algérie (OTA) for US\$ 737 million against US\$ 422 million offered by the second bidder, France Telecom Orange. The second GSM license proceeds were to be paid in two installments. The first installment was paid prior to the issuance of the license in August 2001, while the second was paid in December 31, 2003. The telecommunications financial crisis world wide, as well as the persistent social unrest in the country affected the overall success of the second GSM transaction. Obviously, government officials were disappointed by the sale price, mainly because it was below the US $\$ 1.1$ billion (including VAT) paid by Medi Telecom ${ }^{11}$ to the government of Morocco two years earlier. In contrast to government officials disappointment, most international observers felt that the license was overpaid, and praised the government for implementing a transparent bidding process.

In September 2002, a major press campaign overshadowed the second GSM licensing. The main allegations made in the press were: (a) OTA did not meet the technical qualification criteria, (b) did not have the capacity to develop a GSM operation and would not have been pre-qualified and selected without political intervention; (c) OTA did not fully meet the first-year service obligations attached to its license, (d) OTA's financial situation was weak, and OTA's mother company OTH (Egypt) was excessively leveraged and eventually could be declared bankrupt. Indeed, the company did not meet all the pre-qualification criteria and was pre-qualified on the basis of an escape provision included by the authorities in the tender rules to account for the severe financial crisis affecting potential investors (mostly European Telcos). In

\footnotetext{
9 - connection of at least 1,500,000 mobile subscribers worldwide, operate GSM networks in at least three countries with 500,000 subscribers in each of the country, equity requirement of US\$3billion or stock market value of US\$10billion

${ }^{10}$ - OTH is the mother company that controls OTA (Orascom Telecom Algerie).

11 - a consortium of Telefonica of Spain, Portugal Telecom and Moroccan investors.
} 
qualifying $\mathrm{OTH}$, the objective of the authorities was probably to enhance competition among potential bidders (France Telecom Orange, Telefonica, Portugal Telecom and Telecom Italia), and prevent them from colluding. Nobody knows what would have happened if OTH had not been pre-qualified. Was the government ready to sell it's the second GSM license even though there was sound risk to end up with only one bidder? What would have been the amount of the financial proposal in that situation ? If the government's main motivation was not to sell the second GSM license at the highest price, was its decision to qualify OTH consistent with its reform strategy ? These questions are sound and relevant though we do not have straightforward answers to any of them. The most important lesson learned is that the second GSM licensing process was implemented according to the country's regulations and tender rules. The licensing of the third GSM operator that was concluded in 2003 also highlighted the valuable experience gained by Algeria in reform implementation. As a matter of fact, the comfort and enthusiasm expressed by investors during the third GSM licensing can be explained by a sound track record established by the government of Algeria in ensuring regulatory certainty and predictability. Indeed, the third GSM licensing demonstrated the effectiveness of the regulatory framework established in Algeria. Seven operators were pre-qualified ${ }^{12}$, and three of them submitted financial bids. Watanya Telecom was declared the winner with a financial offer of US $\$ 421$ million against US\$409million for Telefonica and US\$375million for MTN.

\section{PRELIMINARY ASSESSMENT OF THE IMPACT OF THE REFORM}

This section discusses the preliminary impact achieved by the reform implementation, and shows substantial progress made in terms of connectivity, affordability, employment and regulatory practice.

\subsection{EXPANDING ACCESS}

Two years after entering the Algerian market, OTA quickly overcome its financial difficulties, reorganized its operations, and complied with its license service obligations. OTA controlled $70 \%$ of the mobile market and connected approximately one million subscribers most of whom did not have mobile subscription prior to the liberalization (see Fig-7.).

\footnotetext{
12 - These are : Watanya Telecom (Kuwait), Orange France Telecom (France), TurkCell (Turkey), Telefonica (Spain), MTN (South Africa), Maroc Telecom (Morocco), MTC Vodafone (Kuwait).
} 


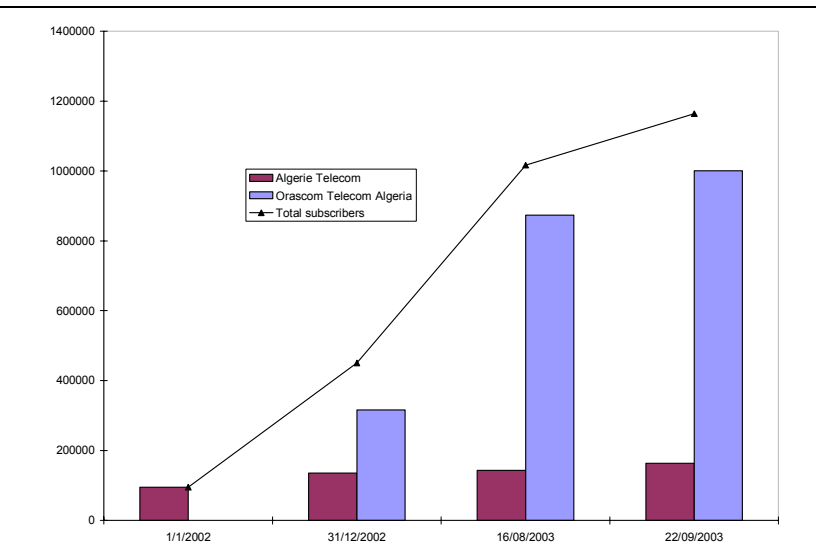

Fig-7- GSM subscribers evolution in Algeria - Source: ARPT (2003)

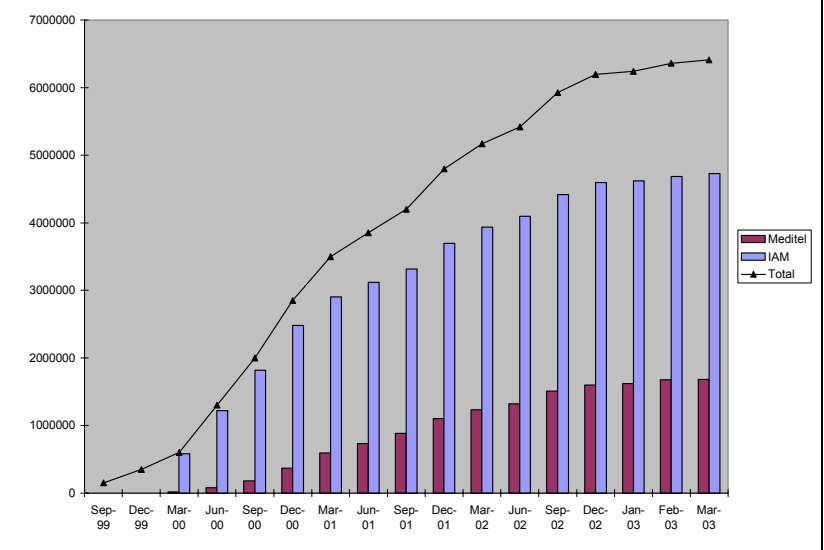

Fig. 7 bis - GSM subscribers growth in Morocco. - Source : ANRT (2003)

In fact, OTA's entry in the Algerian market was facilitated by AT's lack of preparation. As already discussed, AT's transition from a government department into a commercial firm went through a long, complex, and inefficient process. For instance, its mobile network was congested and plans to expand its capacity were stalled in a highly politicized procurement process. A public tender to procure 500,000 lines was launched in November 2001, awarded in April 2002, and declared unsuccessful in November 2002 because of allegations of corruption. In contrast to Morocco, where the public incumbent (Maroc Telecom or IAM) had strong technical and managerial capacity to compete (see Fig. 7bis), AT was not ready to sustain a fierce competition against OTA. Despite the lack of fierce competition in the mobile market, Algeria witnessed $1,525 \%$ increase of the number of mobile subscribers from 1999 to September 2003. The total number of mobile subscribers jumped from 72,000 in 1999 to more than a million in September 2003. The increase in the number of fixed lines was only $25 \%$, from 1,600,000 in 1999 to 2,000,000 by the end of 2002 . Additionally, $32^{13}$ out of 48 wilaya, as well as most national highways are covered mobile networks (ARPT, 2003a, b). Further, the expected entry of a third GSM operator in 2004 has already led to price reduction for connection fees which have been divided by 3 for post - paid subscribers ${ }^{14}$, and by 2 for pre-paid subscribers ${ }^{15}$. Therefore, the government was right in favoring the implementation of market liberalization policies as opposed to corporate restructuring.

\footnotetext{
13 - Wilaya stands for provincial government units.

14 - The average connection fee went down from DH22,000 in 2002 to DH8,054 in 2003.

15 - The average connection fee went down from DH8,900 in 2002 to DH3,999 in 2003
} 


\subsection{IMPROVING SERVICE AFFORDABILITY}

Prior to the reform, telecommunications tariffs were not cost based. Despite huge supply shortages, no major tariff adjustment was implemented. Even for mobile telephony, tariffs generally reflected a strong social component, even though there were only 72,000 mobile subscribers, most of them belonging naturally to the top $10 \%$ highest income. In fact cost recovery was not at the center of the decision process, and little was indeed done to assess costs. Pricing of telecommunications services was not treated differently from other commodities for which the government administered prices. One of the objectives of the reform was to change that, and restate cost recovery as a basic but founding principle. Regarding fixed telephony tariffs, the most urgent action was to rebalance AT's tariffs.

\subsubsection{Fixed telephony rates}

Table-1 depicts a very contrasting situation. The rule of thumb governing tariff rebalancing in telecommunications recommends to implement cost oriented tariffs. This implies to: (a) increase local and monthly subscriptions in order to allow the carrier to recover its costs and make a reasonable return on investment, (b) lower tariffs for domestic long distance and international calls in order to reflect cost reductions allowed by new technologies. Even, after the implementation of ARPT's decision, local rates in Algeria remain seven (7) times lower than in Morocco, and two (2) times lower than in France. Considering that 60 to $65 \%$ of telephony traffic is made of local calls, there is a need to pursue the rebalancing effort in order to provide AT with the financial resources needed to cover its operational and capital costs. Regarding domestic long distance calls, rates in Algeria are 2.5 times lower than in Morocco and Tunisia, and 1.5 times lower than in France. Conversely, rates for international calls are respectively 7 and $17 \%$ higher than in Morocco and France, but $11 \%$ lower than in Tunisia. Overall, the benchmarking exercise shows that the rebalancing effort has not yet gone very far. The difficulty probably lies with social concerns prevailing during pricing decisions. Raising local and domestic long distance rates respectively to the level observed in France and Morocco, and lowering international rates to the level observed in Morocco will provide the incumbent operator with a balanced revenues scheme without its long run viability is at risk.

\subsubsection{Mobile telephony rates}

The differences highlighted on mobile telephony tariffs are even more difficult to explain. Mobile telephony rates are in principle not regulated, but suppliers are subject to anti-competitive regulations on two areas: predatory pricing for retail services, and monopolistic pricing for calls termination. For the purpose of this 
benchmarking exercise, we have defined four categories of mobile telephony services. Intra-mobile service involves mobile calls between subscribers connected to the same mobile operator. In contrast, inter-mobile service stands for calls between subscribers connected to different mobile operators. Mobile-fixed and fixed-mobile services refer respectively to the termination of mobile calls on a fixed network and vice versa. Note however, that if termination rates are subject to symmetric regulations in Algeria, retail price for fixedmobile or mobile-fixed retail services are not regulated.

The review shows that AT's mobile rates are systematically below OTA's rates. This is probably a legacy of the public administration. When benchmarked against rates practiced in neighboring countries, the conclusions are even worse. With respect to intra mobile and inter mobile, AT's rates are respectively onefifth and one-third of rates observed in Morocco. Mobile-fixed rates are one-third of rates observed in Morocco, and Tunisia. Conversely, fixed mobile rates are almost equivalent to rates observed in Morocco and Tunisia. Clearly AT's mobile rates are abnormally low, and raise relevant concern with respect to predatory pricing. By charging lower rates for mobile calls terminating on its fixed network, AT is probably subsidizing mobile calls and therefore distorting competition. This probably explains the regulator's decision released in June 2003, and imposing price floors for Algeria Telecom mobile rates ${ }^{16}$.

\footnotetext{
${ }^{16}$ - According to ARPT's decision on June 2003, the following price floors were set for Algerie Telecom mobile services : 0.057 for intra-mobile; 0.107 for inter-mobile; and 0.072 US $\$$ per minute for mobile-fixed and fixed-mobile services.
} 
Table $-1 .:$ Service affordability impact of the reform

\begin{tabular}{|c|c|c|c|c|c|c|c|c|}
\hline price of calls (US\$/min.) & \multicolumn{2}{|c|}{ Algeria } & \multicolumn{2}{|c|}{ Moroco } & Tunisia & \multicolumn{3}{|c|}{ France } \\
\hline \multicolumn{6}{|c|}{ Fixed service } & \\
\hline Local & \multicolumn{2}{|c|}{0.013} & \multicolumn{2}{|c|}{0.087} & 0.012 & \multicolumn{3}{|c|}{0.025} \\
\hline Domestic long distance & \multicolumn{2}{|c|}{0.044} & \multicolumn{2}{|c|}{0.105} & 0.105 & \multicolumn{3}{|c|}{0.064} \\
\hline International & \multicolumn{2}{|c|}{0.600} & \multicolumn{2}{|c|}{0.559} & 0.668 & \multicolumn{3}{|c|}{0.500} \\
\hline \multicolumn{9}{|c|}{ Mobile services } \\
\hline & $\mathrm{AT}^{*}$ & Djezzy & IAM & Meditel & TT & Orange & SFR & Bouygues \\
\hline Intra-Mobile & 0.041 & 0.081 & 0.15 & 0.15 & 0.138 & 0.275 & 0.313 & 0.288 \\
\hline Inter-Mobile & 0.081 & 0.119 & 0.202 & 0.198 & 0.138 & 0.290 & 0.290 & 0.290 \\
\hline Mobile-Fixed & 0.041 & 0.119 & 0.148 & 0.198 & 0.138 & 0.186 & 0.313 & 0.288 \\
\hline Fixed-Mobile & 0.113 & 0.113 & 0.163 & 0.206 & 0.138 & 0.226 & 0.226 & 0.294 \\
\hline
\end{tabular}

Source: ARPT, June $2003-\left(^{*}\right)$ prices subject to price floors decided by ARPT.

\subsection{PreLIMINARY SOCIAL IMPACT}

The reform has so far been implemented without any employment losses. This has been possible because of a combination of factors and political decisions. First, in order to gain the social support of its reform agenda, the government committed itself to protect employment and refrain from initiating redundancy programs. The 43,000 staff of the ministry of post and telecommunications were therefore transferred respectively to AT $(19,000), \operatorname{AP}(22,000)$, ARPT (30) and around 2,000 remained with the ministry. Second, OTA has created around 1,300 direct employment positions and claimed to have contributed to the creation of 5,000 indirect employment positions. In addition, 15 ISPs and 4,000 cybercafés have also created a significant number of direct employment. In total, the sector has generated a net surplus in terms of employment creation since the launch of the reform program. This positive outcome is likely to be sustainable in the long run, even though the privatization of AT, which has been delayed after 2005, would imply further employment downsizing in the company. Overall, telecommunications revenues generated by licensed operators in Algeria represented 1.5\% of the GDP in 2003 as opposed to $1.06 \%$ in 2002.

Although it is too early to derive any conclusive opinion on the sector reform impact, it is important to underscore that most of the development objectives have been attained. A new regulatory framework and new institutions have been established. The number of service providers has exploded, and competition is progressively taking roots including in the core business that used to fall under the public monopoly. Despite its difficult start, there is hope that AT will also overcome most of its operational weaknesses and 
finally becomes one of the main market player. But, developing sound and sustainable regulatory practice remains the most important challenge to be dealt with in the future. The challenge will be to preserve ARPT's independence from political interferences, and therefore ensuring greater clarity to regulatory process.

\section{LESSONS LEARNED}

The implementation of the reform provides a unique opportunity to grasp many lessons spanning from the identification of critical policy and institutional issues, to the design of the reform, to its packaging, to how to overcome political and social obstacles that arise as the reform becomes effective. Most of these lessons can be framed according to the analytical framework developed by Levy and Spiller (1993). Central to their prescriptive framework is the overall concern to ensure adequacy, and compatibility between proposed regulatory institutions and the country pre-existing patterns of legislative, judicial, administrative and political arrangements. Their framework also stresses the importance of interest group structures as well as formal or informal social norms in setting up new regulatory institutions. In short, the authors argue against a "one size fits all" approach while designing or implementing regulatory reforms in developing countries. In practice, the reform implementation in Algeria showed tensions between the country's ability to commit to a stable set of rules and its ability to respond to changing circumstances in the business environment. Similar tensions are discussed by Gomes-lbanez (2003) in reviewing regulatory reforms in Latin American countries that have been confronted to external financial crises. Levy and Spiller (1993) grouped countries in three categories. A first group includes countries which can design regulatory systems that afford the regulator substantial discretion to respond to changing circumstances and use process to restrain arbitrary action. These are mostly developed countries with sound democratic systems ensuring political accountability through effective check and balance as discussed by Gregg Pallast et al, (2003). A second group is composed of countries that can restrain arbitrary action only by calling on specific substantive rules and may have to sacrifice flexibility to achieve credible commitment. Most developing countries can be grouped within this category. A third group of countries may lack the domestic institutions to put in place a credible and workable regulatory system of any kind. The classification is sound, but does not explicitly take into account the importance of political will behind the expression of any government's commitment. Most importantly, political will is expressed on a case by case basis, and namely according to expected political returns. Political leaders behave like entrepreneurs in the sense that they are inclined to support projects yielding highest political returns. This also applies to regulatory reforms. One should therefore 
anticipate that the most rewarding reforms benefit from leaders' commitment to restrain arbitrary political actions. This is indeed, the main lesson derived from the implementation of the telecommunications reform in Algeria. The licensing of GSM operators seem to have been highly ranked in the government's list of priorities and accordingly have benefited from exceptional political support. Conversely, the corporate restructuring component of the reform was not a top priority on the government agenda and was consequently more exposed to political interference. The remainder of the section discusses three main lessons: political will and commitment, pragmatism, and indigenous solutions.

\subsection{POLITICAL WILL AND COMMITMENT}

The sector liberalization is now irreversible, and the days of public monopoly in the telecommunications sector are definitively a souvenir for most Algerians. The political skills with which the process was handled by senior government officials made the reform possible. Contrary to other structural reforms, many times announced but never implemented, the telecommunications reform made a remarkable breakthrough and demonstrated that change and transformation were possible in Algeria, despite a difficult political context. How this has been possible requires additional research by political scientists. For this paper, we propose the following factors. First, there was a strong political will and commitment to reform the post and telecommunications sector in order to provide the Algerian economy with advanced communication services at competitive terms. Second, the program implementation was supervised by a pragmatic but very experienced line minister who knew how to set priorities and build or ensure political consensus. Contrary to other developing countries, the telecommunications reform in Algeria was not an outcome of an economic adjustment operation managed at the ministry of finance and economic affairs. It was dealt with at the ministry of post and telecommunications, which despite its very limited capacity, was empowered to conduct the program while also ensuring political and social consensus. As a result, the government was able to publish, during the first 12 months of the reform implementation, a pro-liberal sector policy and enacted most regulations needed to dismantle the public monopoly over the provision of telecommunications services. The licensing of the second GSM operator was consequently launched in parallel to the establishment of the new regulatory framework. Third, the sequencing of the reform pace gave priority to the implementation of market liberalization policies on which there was broad consensus among political leaders. Although public enterprise privatization was strongly opposed by labor unions and most political parties, there was little opposition to opening up the telecommunications sector to competition. 


\subsection{Pragmatism}

In a fragile institutional environment, namely characterized by political instability and social turmoil, reforming is a matter of capacity to take and manage political risks. International financial institutions should be ready to bear some of the risks for any government to succeed. This is what the World Bank did. A technical assistance project of US $\$ 9$ million was put together by the Bank in around five months despite perceived policy, regulatory, and social risks not properly mitigated by the government's program. Indeed, the main risks were linked to the reform pace and sequencing. The government wanted to introduce competition in the mobile (GSM) market segment, but was not prepared to go through a comprehensive reform that will require time to develop and establish a sound regulatory regime. The challenge was indeed to reconcile the requirements of a comprehensive sector reform and the short-term political objectives that the government wanted to achieve through a successful sale of GSM licenses in 2001 and 2003, respectively. The project team wisely factored in the sale of the second GSM license as one of the main outcomes, and designed the remainder of the comprehensive reform around the achievement of that goal. Consequently, the sector policy and the law were prepared in parallel, as well as all the secondary regulations. Specific assistance was devoted to develop the new regulatory framework, including the technical assistance to the newly created regulator, and to assist the government in the GSM licensing. The organizational and financial restructuring of the ministry activities were unbundled from the licensing and handled in parallel. In supporting a pragmatic approach, the World Bank was able to provide the ingredients required for a breakthrough of the telecommunications sector reform in Algeria. Indeed, the sale of the GSM license provided an exceptional window of opportunity that the World Bank and the government seized to lay down the foundations for sustainable growth in the telecommunications. Departing from its standard model of sector restructuring, the World Bank team put the Algerians at the driving seat of the reform process and provided policy guidance as needed. 


\subsection{INDIGENOUS SOLUTIONS}

The regulatory reform was however very complex, namely because of the mismatch between some of the regulatory principles underlying the proposed reform (transparency, competitive tender, regulator's independence, regulatory certainty and predictability,...) and the day to day governance practices in Algeria. As Algeria was opening up its economy to international trade, the government was keen to learn from international experience or best practices but urged its representatives to devote the best they could in adapting these models to the Algerian context. The government did not want to replicate imported models not necessarily adapted to local realities. For example, in contrast to international best practice, the government opposed the implementation of a wide consultative process in devising and implementing the reform. The government argued that public consultations will delay the reform implementation at best, or undermine the reform momentum at worst. To proceed with a fast track reform, consultations with stakeholders were kept at minimum. However, "closed doors" meetings were held regularly with labor unions' representatives. The supportive attitude of the labor unions throughout the reform implementation can also be explained by direct access that their leaders had to the sector minister. Only very few people, including among the staff of the ministry, knew the details of the reform program. Secrecy was the rule, and was to some extent point counter productive as illustrated later during the OTA's press campaign that we have mentioned earlier. Furthermore, a communication campaign was prepared with the help of an international consulting firm, but was never implemented in practice. An internal magazine disseminating information about the reform was elaborated, but never released. Overall, the government wanted to avoid public discussion about the reform program, and thought that restraining public debate on the reform was the right attitude to ensure its implementation. The government objective was to complete the corporate restructuring effort without any strike or strong opposition from the labor unions. That goal was effectively attained.

\section{CONCLUSION}

This paper has shown that a regulatory reform is a learning by doing experience that deviates sometimes from the standard track prescribed in text books. This probably stems from the difficulties in developing and establishing the "rule of law practice" in countries where separation of powers and political accountability remain weak. In Algeria, many disputes quickly developed between the regulator and the line ministry despite the clarity of the regulatory framework. For example, the regulatory body persistently refused to share information with the line ministry because the law did not expressly require it to do so. The 
cooperative spirit that should have prevailed between policy and regulation did not develop because of a narrow reading of the legislation. Nevertheless, the divergence in interpretation never developed into a crisis, and pragmatic compromises were always found. As shown in the paper, the connectivity to fixed and mobile telephony and the Internet has significantly improved since the reform was launched, and will continue to improve as competition consolidates in the market. The main uncertainties facing the development of the sector are mostly political in nature and entail two policy recommendations: (a) the government must at least maintain or increase its political support to the sector reform by building the capacity of newly established institutions including developing new skills required; and (b) the delays affecting the incorporation of AT require more effective measures and actions (operational, organizational, financial, etc.) from the shareholders. Unless AT's weaknesses are effectively addressed, the long-run sustainability of the reform will remain at risk.

Overall, the telecommunications reform not only seeded the conditions for sustainable growth and development in the sector, but has also impacted reforms in at least two other sectors. First, the government launched a broad reform program in the energy sector involving restructuring of the oil sector as well as reform of the electricity sector. In the latter, the enactment of new legislation led to the unbundling of the electricity market (generation, transmission, distribution) and the establishment of an electricity regulatory board. Second, a tender was organized to privatize the international airport in Algiers, though unsuccessfully.

\section{REFERENCES}

Pallast, G; Oppenheim, J; and McGregor, T (2003), Democracy and regulation - how the public can govern essential services, Pluto Press

Gomez-lbanez, J (2003), Regulating infrastructure - Monopoly, Contracts, and Discretion, Harvard University Press.

Levy, Brian and Spiller, Pablo (1993), "Regulation, Institution, and Commitment in Telecommunications - a comparative analysis of five country studies", in Proceedings of the World Bank annual conference on development economics, pp. 215-52.

World Bank (2003), Foundations for the development of ICT in Algeria, ESW Report No 25841, Washington $\mathrm{DC}$

World Bank (2002), A medium term macro-economic strategy for Algeria, mimeo, Washington DC

World Bank (2000), Appraisal report No 20509 AL, Post and Telecommunications sector reform loan, mimeo, Washington DC 